\title{
A QUALITATIVE STUDY ABOUT RELIEFS MEANING OF PLAOSAN TEMPLE: THE BUDDHIST TOURISM DESTINATION AT KLATEN, CENTRAL JAVA
}

\author{
Arina Afiyati Shadikah \\ Sekolah Tinggi Agama Buddha Negeri Raden Wijaya Wonogiri, 57651, Indonesia \\ arina.jurnal@gmail.com
}

\begin{abstract}
This study belongs to qualitative research. This recent study focuses on the history of Plaosan temple and the reliefs meaning existed at Plaosan Temple located at Klaten Regency, Central Java. The subject of this study was the Plaosan temple itself. This study aims to identify reliefs meaning of Plaosan temple and also the history of it. The method of this study is qualitative. The data were collected using observation, interview, and documentations. The data collected were analyzed qualitatively. The history of Plaosan temple was taken from the interview with an archeologies at Central Java Institute for Preservation of Cultural Heritage and documentation from some sources founded at the library of this institute. The reliefs meaning was taken from the interview. However, the observation was done for the preliminary study. The research finding showed that there were there were three types of reliefs of Plaosan temple. Those were shaped characters, ornamental decoration, and animals. Each relief character had their own meaning. Character involved the character of a man and a woman which symbolized gender equality existed in the past, ornamental decoration about plants and tendrils showed about human's life, and animal reliefs that consist mythological animals of Kara and Makara symbolized about reminder and teachings for human being.

Keywords: Qualitative study, relief meaning,Plaosan temple.
\end{abstract}

\section{INTRODUCTION}

Tourism takes important role in every country. It becomes one of biggest income for the country. For instance, Spain, France, USA, Japan, and other countries. Those countries have the highest income from tourism field. The more tourist destination a country has the bigger income it gets from that field.

Indonesia is a very beautiful country that also has many tourism destinations. They can be nature, ancient buildings, and even culture. There are some ancient building existed. Those are some of historical legacies in the past. Some are Dutch heritage. Some are relics, such as relics of Islam, relics of Hinduism, and relics of Buddhism. Indonesia is rich of religious tourism destinations. One of the most popular religious tourism destination in Indonesia is Borobudur

Al Qalam: Jurnal Ilmiah Keagamaan dan Kemasyarakatan Vol. 16, No. 1

Januari - Juni 2022 
Arina Afiyati Shadikah : A Qualitative Studi About Reliefs Meaning of Plaosan Temple : The Buddhist Tourism Destination at Klaten, Central Java

temple. It is one of Buddhist relics lied in Indonesia. It is also popular as the biggest Buddhist temple in the world and located in Indonesia, especially Central Java.

Because of those facts above, there is tourism that is taught as one of lesson in university. This is for promoting tourist resort in Indonesia. For Buddhist Institution, there is specific tourism lesson that is called Buddhist Tourism. It is intended to promote Buddhist tourism in Indonesia. That is why the students must be taught Buddhist tourism subject.

At Sekolah Tinggi Agama Buddha Negeri Raden Wijaya Wonogiri (STABN Raden Wijaya Wonogiri), the students also get English tourism subject at the sixth semester. There are some materials taught for them related to English tourism especially Buddhist tourism. However, some of them are still general. For instance, the students get material about the airport and the hotel. Those are not specific yet since they have to study English for Buddhist tourism. Therefore, the researcher tries to find another material that is related to Buddhist tourism. It is about the meaning of temple relief.

There are some temples located near STABN Raden Wijaya Wonogiri, such as Plaosan temple, Kalasan temple, Sewu temple, Borobudur temple, and others. In this research, the researcher will take Plaosan temple as the place to do the research. It is one of small Buddhist temple in Yogyakarta that still needs to be investigated more about the relief meaning of that temple. Based on the background of the study above, the researcher will focus on the relief meaning of Plaosan temple, Klaten, Central Java.

\section{LITERATURE REVIEW}

There are three important terms that will be presented to underlie theory about relief meaning of Buddhist temple. They are temple, relief, and Buddhist tourism.

Wirasanti (2016) defines temples as cultural phenomenon of the past which are designed completely with its yard spatial layout establishing sacred space that were built in a place close to its supporting community ${ }^{1}$. Temple consists of three parts. Those are stated by Aji (2018). He states that temples are divided into three parts. They are temple's foot, temple's body, and temple's roof ${ }^{2}$. In addition, relief is also one of important element must be existed in a temple. Relief is one of Hinduism-Buddhism culture heritage which can be found in religious buildings (Darini, 2016). As we know that Hinduism-Buddhism religious place is temple and monastery, it

\footnotetext{
${ }^{1}$ Wirasanti, Niken. 2016. Struktur dan Sistem Tanda Ruang Sakral Candi (Kasus Candi-Candi Masa Mataram Kuna Abad IX Masehi). International

${ }^{2}$ Aji, Artbanu Wishnu. 2018. Candi-Candi di Jawa Tengah dan Yogyakarta. DIY: BP ISI Yogyakarta
}

Al Qalam: Jurnal Ilmiah Keagamaan dan Kemasyarakatan Vol. 16, No. 1

Januari - Juni 2022 
Arina Afiyati Shadikah : A Qualitative Studi About Reliefs Meaning of Plaosan Temple : The Buddhist Tourism Destination at Klaten, Central Java

can be explained that relief can be found in those religious places. ${ }^{3}$

Buddhist tourism destination is all kinds of tourism destinations that are related to Buddhism. They can be Buddhist temples, Buddhist monasteries, Buddhist museums, or any other interesting places that have relationship with Buddhism. Temple is one of Buddhist tourism destination that can be enjoyed. There were some related studies about reliefs meaning proposed by some researcher. Hendriyana et.al (2014) studied about meanings and symbols of Dalima Relief in Keraton Kasepuhan Cirebon. ${ }^{4}$

Wahyudi and Jati's work in 2014 explored about Relief Ari Darma at Jago Temple and identified the usage of Ari Daram story in temple context. ${ }^{5}$ The next researcher was Soedjono in 2015 who studied about Ramayana Relief of Prambanan temple which explored reliefs based on legendary story of Ramayana. ${ }^{6}$ The last one was Auliasari and Orisa in 2017 that studied about the use of algorithm to identify Relief image. ${ }^{7}$

From those four studies, the researcher found a gap among them. It was about the Buddhist temple. Therefore, the aim of the present study was to find out the reliefs meaning at one of Buddhist Temple in Central Java, especially at Klaten named Plaosan temple. Besides, this study also reveals the history of Plaosan Temple.

\section{RESEARCH METHODOLOGY}

The method of this study is qualitative. The researcher used and hope this design can give detail and in depth information about certain phenomenon. Cresswell (2009) identified qualitative research as an investigative method for understanding a phenomenon based on separate methodological traditions of inquiry that elicit human conditions or social problem. ${ }^{8}$ Prastowo (2014) in his book states that there are four purposes of qualitative research. They are finding interactive relationship scheme, developing complex reality, getting meaning understanding, and finding theory. ${ }^{9}$ Qualitative research does the same, although with perhaps more emphasis on

${ }^{3}$ Darini, Ririn. 2016. Sejarah Kebudayaan Indonesia Masa Hindu-Buddha. Yogyakarta: Penerbit Ombak.

${ }^{4}$ Hendriyana, et.al. 2014. Meanings and Symbols of Dalima Relief in Keraton Kasepuhan Cirebon. International Journal of Creative and Art Studies, p.19-24.

5 Wahyudi, Deny Yudo and Slamet Sujud Purnawan Jati. 2014. Relief Ari Darma di Candi Jago. Jurnal Sejarah dan Budaya, 8 (2).

${ }^{6}$ Soedjono. 2015. Creative by Way of Adaptation: Ramayana Relief of Prambanan Temple. Jurnal of Urban Society's Art, 2 (2)

7 Auliasari, Karina and Mira Orisa. 2017. Algorithm for Identifying Objects in The Relief Image Using Watershed Segmentation Scientific Journal of Informatics, 4(2), 104-114

${ }^{8}$ Cresswell, J. (2009). Research Design: Qualitative and Quantitative Approaches. London: SAGE.

${ }^{9}$ Prastowo, Andi. 2014. Metode Penelitian Kualitatif dalam Perspektif Rancangan Penelitian. Jakarta: Arruzz Media

Al Qalam: Jurnal Ilmiah Keagamaan dan Kemasyarakatan Vol. 16, No. 1 Januari - Juni 2022 
Arina Afiyati Shadikah : A Qualitative Studi About Reliefs Meaning of Plaosan Temple : The Buddhist Tourism Destination at Klaten, Central Java

expository writing in which historical research relies on narrative. Thus, the researcher used this method to explore relief meaning and temple's history. In addition, the researcher is the main instrument of analyzing the data. The subject of this research is Plaosan Temple located at Klaten Regency, Central Java.

This study used interview and documents to collect the data. McNamara (1999) explains that interviews are particularly useful for getting the story behind a participant's experiences. ${ }^{10}$ The researcher used this technique to collect the data. Besides, the documents from the temple such as the written ads, books, and photographs are also analyzed qualitatively. Those techniques are used to find out the meaning of relief temple of Plaosan and its history.

\section{FINDINGS AND DISCUSSION}

\section{History of Plaosan Temple}

There is a long history of Plaosan temple that was taken from documents of Institute for Preservation of Cultural Heritage in Central Java's studies (2002). ${ }^{11}$ Plaosan temple is Tentrayana Buddhist Temple. Plaosan comes from the word "pe-Laos-an" that may have relationship with a country named Laos. Basically, Buddhist temples have three forms of Buddha, they are Diani Buddha, Diani Bodhisattva, and Manusi Bodhisattva. Some statues at Plaosan temple have certain meaning, such as Buddhist statue in the middle of Diani Buddha (Vahirocana) and bodhisattva. The red one is awalukiswara, the symbol of affection. The yellow one is vajvarani, the symbol of wisdom.

Plaosan temple pattern is embodiment of Triratna, they are Buddha that means the truth; Dharma that means way to reach the truth; and Sangha that means holy communion (place for teaching and learning by teacher and students that are delegated by monks. Those three terms are the keys to meet The Eternal. The statue symbols at Plaosan Temple are not about Buddhist symbol as himself, but the symbol of Buddha as eternity of perfection in which that symbol is flanked by two Bodhisattvas. It is the symbol which wants to reach perfection.

Buddhist Tentrayana is full of symbols that have long meaning. This is shown by Bodhisattva statue at Plaosan temple which symbolizes each form and nature of Buddha and also way to contemplation of virtue. Those symbols have mystic character. What recently happens is that people do not care about worshipping anymore, but they only care about the culture of

\footnotetext{
${ }^{10}$ McNamara, Carter, PhD. General Guidelines for Conducting Interviews, Minnesota, 1999

11 Wardhani, Septina et. al. 2002. Studi Pelestarian dan Pengembangan Candi Plaosan. Suaka Peninggalan Sejarah dan Purbakala Jawa Tengah. Klaten: Balai Pelestarian dan Cagar Budaya Jawa Tengah
}

Al Qalam: Jurnal Ilmiah Keagamaan dan Kemasyarakatan Vol. 16, No. 1 Januari - Juni 2022 
Arina Afiyati Shadikah : A Qualitative Studi About Reliefs Meaning of Plaosan Temple : The Buddhist Tourism Destination at Klaten, Central Java

symbols. This is of course rule out worshipping element which should be someone's main goal in life. On the $7^{\text {th }}$ and $8^{\text {th }}$ Century (period of Plaosan establishment), it is about concept maturation of Tentrayana which then creates new concept called Adibudha. It means perfection of Buddha. In Indonesia, it is embodied by The One Almighty God. The same Tentra was also found in Tibet. It was originally from Indonesia which was blended in Tentris and local spells. It also happened in Indonesia where the process of change from Buddha of Theravada became Mahayana and then became Tentrayana.

People needed to understand first the basic symbols of Mahayana if they wanted to understand the symbols of Tentrayana. If they wanted to know the symbols of Mahayana, they had to understand first about the symbols og Theravada. This achievement must be understood from the beginning so that it would not cause higher misunderstanding. These high level teachings were adapted to the ability level of a monk where there were only certain monks who got Tentrayana teaching secretly. Hierarchically, the first one is Theravada Buddha (pure) where there is no ritual ceremony. Then, Mahayana was born with big ceremonies and also spread Buddha teachings with their symbols to public at that time.

Seen by some aspects, Plaosan temple has high potential to be developed. In terms of form, Plaosan has three rooms that symbolize Tri Ratna. They are Buddha in the past, Buddha at present, and Buddha in the future. Seen from the arena pattern, Plaosan temple has complete arena pattern from the lowest place (microcosm/ grounded), higher, and the highest place. This is marked by the top of stupa as the embodiment of unity with the heaven/ perfection/ macrocosm. Plaosan temple is a holy place for Buddhist. It must have fences as the safety utility. Those fences and also ditches at Plaosan temple are rated as safety utility from tame and wild animals, so that they cannot swim to reach the surface of Plaosan temple.

Seen from ritual aspect, Tentrayana built at Plaosan temple, the ritual patterns use incantation. Incantation is summary of Buddhist teachings which consist of Terawada, Mahayana, and Tentrayana. Terawada is the most beginning teachings/ sayings of Buddha which is added by comment from Mahayana, and summarized by Tentrayana from holy book (the beginning teaching and information) only become few sentences. However, his sayings are interpreted as understanding the whole content of the holy book. In a religious ceremony, the incantation is read repeatedly to erase bad things so that everyone always thinks about good things. If mind is well thought, so do the sayings and behaviors. The last purpose of all of them is to keep humans' mind to be good as always.

Plaosan temple has two main temples. They are Plaosan Lor and Plaosan Kidul. There are sound some inscriptions or short writings which are carved at some of temple building or on the

\section{Al Qalam: Jurnal Ilmiah Keagamaan dan Kemasyarakatan Vol. 16, No. 1 Januari - Juni 2022}


Arina Afiyati Shadikah : A Qualitative Studi About Reliefs Meaning of Plaosan Temple : The Buddhist Tourism Destination at Klaten, Central Java

gold and silver plate which contain incantations at the Plaosan Lor. The researches at Plaosan temple started since Dutch Colonial period. The research now is done to reveal historical and archaeological aspects of this temple. There were not only researches done, but also restorations were done at Plaosan temple. There were two main temples, two ancillary stupa, three ancillary temples, three gates that are located at the first field gate, four peg temples, and building $\mathrm{C}$ (pendopo) that had been restored since 1940. Meanwhile, there were two ancillary temples that had been restored of Plaosan Kidu complex. The south main temple was restored completely in 1960 and the north main temple was completely restored in 1997.

Based on those researches and restorations, it could be revealed that there are some interesting things. They are: (1) Plaosan is surrounded by ditch. It has square form. It is about 440 x 270 meters. Width of the ditch is about 10 meters with 2,5 meters depth.; (2) Out of the ditch are surrounded by four square fences with $460 \times 290$ meters length. The discovery of this ditch and haw shows that Plaosan Lor and Kidul is a wide temple complex; and (3) Two main temples (Plaosan Lor and Kidul) are twin buildings with exceptional structure. The special thing is that there are two floors building with different number of temple cubicle to other temples. Each main temple has 6 cubicles, they are three on the downstairs and three on the upstairs.

So far, there is only Plaosan temple which has haw. The beauty of statues, temple's reliefs, and inscriptions on Perwara temples which mention the names of officials on ancient Mataram time who took part in building the temple makes this temple interesting for the researchers and societies.

Administratively, Plaosan temple is located in Bugisan, Prambanan, Klaten. It is surrounded by Kebondalem Lor village at the north side, Kemuda village at the east side, Taji village at the south side, and Bugisan village at the west side. There is a river named Dengok on the north side. Geographically, Plaosan temple is located at the tropical area which has two seasons, they are rainy and dry season. Climatologically, it can be identified as follow: (1) The average temperature is about $26,74^{\circ}$ Celsius. The lower air temperature is about $19^{\circ}$ Celsius and the maximum temperature is about $31,06^{\circ}$ Celsius with the highest air temperature is about $38,5^{\circ}$ Celsius. The average air humidity is about $86,75 \%$ and the acerage water evaporation is 5,59 $\mathrm{kg} / \mathrm{m}^{2}$ and (2) The average rainfall is up to $100 \mathrm{~mm}$ per month and the highest rainfall is about $491,9 \mathrm{~mm}$ with $71 \%$ rainy day per year.

Plaosan temple has ideal rice field because of the fertile soil and supported by irrigation from the river near to the temple. Besides, there are some trees that can be used as ritual activity. The location selection in building Plaosan temple seems to consider the environment resource such as water resource, land condition, and type of soil.

\section{Al Qalam: Jurnal Ilmiah Keagamaan dan Kemasyarakatan Vol. 16, No. 1 Januari - Juni 2022}


Arina Afiyati Shadikah : A Qualitative Studi About Reliefs Meaning of Plaosan Temple : The Buddhist Tourism Destination at Klaten, Central Java

\section{Reliefs Meaning of Plaosan Temple}

There are three reliefs existed on Plaosan temple. Each relief has its own meaning, the result was got from the intervier with a cultural conservation preserver of Central Java. He stated that there are three types of reliefs at Plaosan temple. Those are character, ornamental decorations, and animals. At plaosan temple, there is no story about Buddha journey, but there are some characters of Buddha found at the relief. There are three types of reliefs of Plaosan temple. Those are characters, ornamental decoration, and animals.

\section{Relief of Characters}

There are some characters which are existed at Plaosan temple. Most of relief carved out at the walls of Plaosan temple are Buddhist characters and other important characters. It also consists of Buddhist God relief at Plaosan temple. Those characters are a man and a woman. However, there is no story behind this relief, but it has certain meaning. The name of the characters is also unknown until now. The most important thing is that those characters take important role at the development of ancient Mataram time. It illustrates human life at that time. Based on the male and female character relief, there is specific meaning. It is about gender equality. Here are the reliefs of characters:

Figure 1. Reliefs of Characters

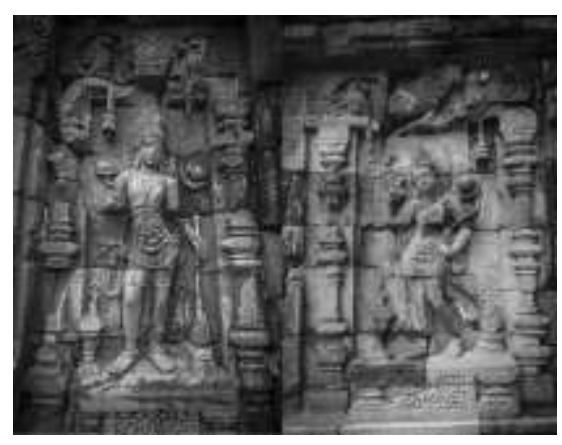

Based on the figure 1 above, it can be seen that there are relief of character. The characters are about male and female character. It shows that Plaosan temple is the proof that is gender equality because male and female characters are showed and placed side by side. There is something we can learn. It is about wisdom that we must be able to respect gender equality because God created male and female without any diversity. Since there is no diversity between male and female, they can live a life together. Thus, they are carved out at the walls of two main Temples of Plaosan.

\section{Relief of Ornamental Decaration}

Plaosan temple also has beautiful relief about ornamental decoration. Since temple is

Al Qalam: Jurnal Ilmiah Keagamaan dan Kemasyarakatan Vol. 16, No. 1

Januari - Juni 2022 
replica of the universe, it is about the relationship to God, human, and environment. The data is taken from the documentation at Institute for Preservation of Cultural Heritage of Central Java. This ornamental decoration consists of plants and tendrils that symbolize human's life in this world must be able to harmonize the relationship with God, other people, and nature environment that we must preserve and keep well. Here are the figures of ornamental decoration relief at Plaosan temple:

Figure 2. Ornamental Decoration Relief

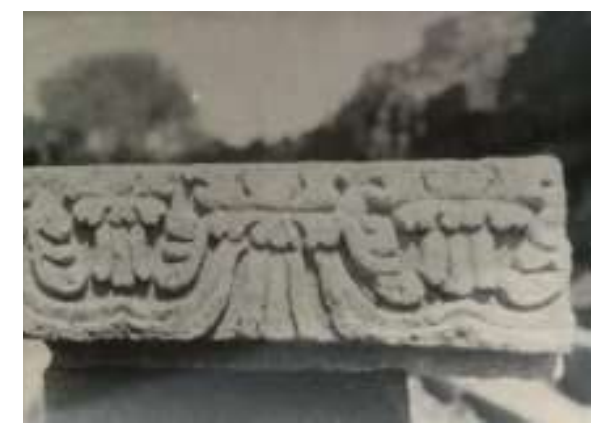

\section{Relief of Animals}

The last relief of Plaosan temple is about animals. They are birds and mythological animals. Birds reliefs symbolize about what people see at that time are carved out at the temple walls. It is about the elements that are inseparable for human being. Here is the figure of birds relief at Plaosan temple:

Figure 3. Bird Reliefs

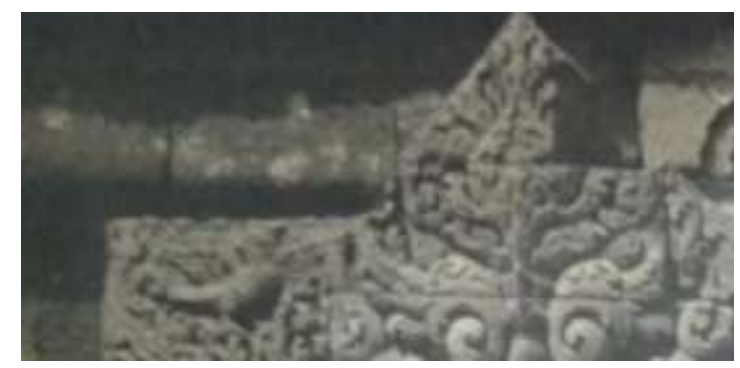

The next is mythological animals. There are two mythological animal reliefs at Plaosan temple, they are Kala and Makara. Kala is placed on the temple's door. The look is so scary. Actually, it has certain meaning. People are reminded to have pure heart when they want to enter a holy place. If they do not, so Kala will warn them. That is the main role of Kala at Plaosan temple. Here is the figure of kala relief at Plaosan temple:

Al Qalam: Jurnal Ilmiah Keagamaan dan Kemasyarakatan Vol. 16, No. 1 Januari - Juni 2022 
Figure 4. Kala Relief

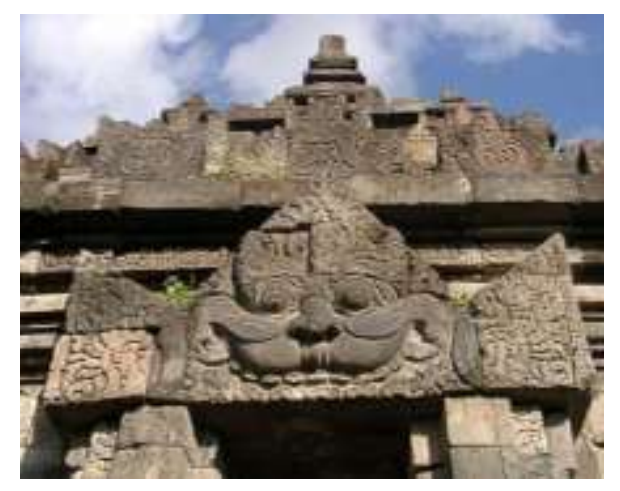

The second one is Makara. It is located at the cheek stair of the temple. The figure is like a snake. This relief has certain meaning as well. It is as repellent and doorkeeper for those who want to enter rooms at Plaosan Temple. Here is the figure of Makara relief at Plaosan temple:

Figure 5. Makara Relief

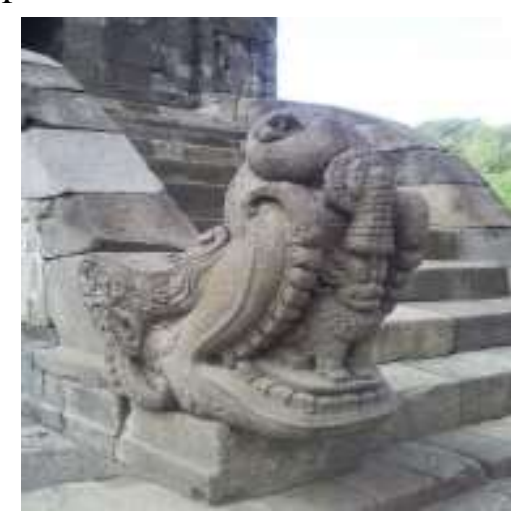

Based on the research finding, there are three reliefs existed on Plaosan Temple. Those are Character reliefs, ornamental reliefs, and animal reliefs. Each relief has their own meaning. For character reliefs, it shows about gender. There are male and female character which indicates that there are gender equality. It is exist since Plaosan Temple was built. The next relief is about ornamental decoration. There are not only characters on Plaosan temple relief, but also ornamental decorations were also sculpted there. Those symbolize about life harmonization. It can be human's relation to God, other people, or nature. The last relief is about animals. There are some animal reliefs such as birds and two mythological animals named Kala and Makara. The birds symbolize about inspiration. People need inspiration from what they see. By seeing birds, they may get inspiration. This is the meaning of birds were sculpted at Plaosan temple.

The second discussion is about the history of Plaosan temple. Based on the research finding, it can be seen that Plaosan temple is Tentrayan Buddhist temple. However, Plaosan temple has different history from each researcher who did research towards this temple. Hence,

Al Qalam: Jurnal Ilmiah Keagamaan dan Kemasyarakatan Vol. 16, No. 1 Januari - Juni 2022 
Arina Afiyati Shadikah : A Qualitative Studi About Reliefs Meaning of Plaosan Temple : The Buddhist Tourism Destination at Klaten, Central Java

the one which is often used is from J.G de Casparis. Plaosan temple was built by Samaratungga's daughter named Sri Kahulunan identifically as Pramodhawardani and helped by her husband named Rakai Pikatan.

\section{CONCLUSION AND SUGGESTIONS}

Based on the research finding and discussion above, it can be drawn conclusion that there are three reliefs found at Plaosan temple. They are character relief, ornamental decoration, and animal reliefs. Each relief has its own meaning. All of them have close connection with human life and teachings in life. However, the history of Plaosan temple is not certain yet because there are many researcher who found different findings to each.

The writer hopes that there will be many researchers who conduct the same topic researches. Thus, Plaosan temple will give more benefits in the field of research findings.

\section{REFERENCES}

Aji, Artbanu Wishnu. 2018. Candi-Candi di Jawa Tengah dan Yogyakarta. DIY: BP ISI Yogyakarta

Cresswell, J. (2009). Research Design: Qualitative and Quantitative Approaches. London: SAGE.

Darini, Ririn. 2016. Sejarah Kebudayaan Indonesia Masa Hindu-Buddha. Yogyakarta: Penerbit Ombak.

Hendriyana, et.al. 2014. Meanings and Symbols of Dalima Relief in Keraton Kasepuhan Cirebon. International Journal of Creative and Art Studies, p.19-24.

McNamara, Carter, PhD. General Guidelines for Conducting Interviews, Minnesota, 1999

Prastowo, Andi. 2014. Metode Penelitian Kualitatif dalam Perspektif Rancangan Penelitian. Jakarta: Arruzz Media

Seminar Prasasti III: Current Research in Linguistics, 562-567

Soedjono. 2015. Creative by Way of Adaptation: Ramayana Relief of Prambanan Temple. Jurnal of Urban Society's Art, 2 (2)

Wahyudi, Deny Yudo and Slamet Sujud Purnawan Jati. 2014. Relief Ari Darma di Candi Jago. Jurnal Sejarah dan Budaya, 8 (2).

Wardhani, Septina et. al. 2002. Studi Pelestarian dan Pengembangan Candi Plaosan. Suaka Peninggalan Sejarah dan Purbakala Jawa Tengah. Klaten: Balai Pelestarian dan Cagar Budaya Jawa Tengah

Wirasanti, Niken. 2016. Struktur dan Sistem Tanda Ruang Sakral Candi (Kasus Candi-Candi Masa Mataram Kuna Abad IX Masehi). International

Al Qalam: Jurnal Ilmiah Keagamaan dan Kemasyarakatan Vol. 16, No. 1

Januari - Juni 2022 